\title{
PLASMA PROTEIN AND PLASMA COLLOID OSMOTIC PRESSURE IN PATHOLOGICAL CONDITIONS WITH SPECIAL REFERENCE TO THE OCCURRENCE OF EDEMA $^{1}$
}

\author{
BY EDWARD MUNTWYLER, CHARLES T. WAY, DOROTHY BINNS \\ AND VICTOR C. MYERS \\ (From the Department of Biochemistry, School of Medicine, \\ Western Reserve University, Cleveland)
}

(Received for publication June 9, 1932)

During the last few years increasing importance has been attributed to changes of the plasma protein concentration in cases of nephritis. Moore and Van Slyke (1930) state that they find the relationship of plasma protein content to the tendency to edema formation to be so regular that they have come to use the plasma protein content no less than the urea excreting function in diagnosing the potential condition of patients and deciding on therapy.

The importance of the osmotic pressure of the plasma colloids for fluid exchange in the organism was first pointed out in the fundamental studies of Starling (1896). Starling observed that the osmotic pressure of the proteins of the serum was about 30 to $40 \mathrm{~mm}$. $\mathrm{Hg}$ and stated that whereas capillary pressure determines transudation, the osmotic pressure of the proteins of the serum determines absorption. Clinically, Epstein (1917) showed that the edema of cases which he originally termed "chronic parenchymatous nephritis" is associated with a lowered protein content of the plasma. The hypothesis which he proposed to explain the production of edema in these cases is briefly as follows. The loss of protein incurred by the blood serum through continuous albuminuria causes a decrease in the osmotic pressure of the blood which favors retention of fluid by the tissues.

In connection with a study of the various types of nephritis, which was begun some time ago in this laboratory, it seemed desirable to follow the changes of the plasma colloid osmotic pressure in conjunction with changes of the plasma protein concentration in the course of the disease.

\section{TECHNIQUE}

A method similar to that of Mayrs (1926) was employed for the plasma colloid osmotic pressure measurements. Collodion sacs of from 4 to $5 \mathrm{cc}$.

${ }^{1}$ This investigation was aided by a grant from the Josiah Macy, Jr., Foundation. 
capacity were made using a 5 per cent solution of Schering's celloidin in a mixture of 75 parts of absolute alcohol and 25 parts of anhydrous ether. The sacs were all prepared as uniformly as possible. A test tube of the desired size was filled with the collodion. After the air bubbles had risen to the top, the collodion was poured out while the test tube was rotated until only about $1 / 5$ the original volume was left. The collodion was then uniformly distributed over the walls of the tube by slowly rotating for 5 minutes. At the end of this time the tube was placed in an inverted position to allow the excess collodion to drain and to dry for 30 minutes. The tube was then immersed in water and the sac removed. The sac was firmly tied to a small one holed rubber stopper, which contained a small piece of glass tubing at the end at which the sac was tied, to prevent collapsing of stopper. An $0.8 \mathrm{~mm}$. bore barometer tubing was inserted into the large end of the stopper and served as the manometer. All sacs were tested for leaks before use.

The plasma employed in this study was obtained from blood drawn under oil from an arm vein before breakfast and without stasis. Neutral potassium oxalate was used as the anticoagulant. In some instances serum was obtained by allowing the blood to clot under oil. Enough of the plasma or serum obtained after centrifuging the sample was introduced into the collodion sac so that when the barometer tube was inserted into the rubber stopper the plasma was forced up into the tube. The determinations were always done in duplicate or triplicate. The plasma in the barometer tube of one of the duplicates was adjusted to a height greater than the anticipated final height, and in that of the other to a height somewhat lower. This was done in order to help correct for any dilution or concentration of the plasma which might occur as the result of the rise or fall of the height of the plasma in the barometer tube. Equilibrium was usually attained at the end of six hours. After this period there was very little change in the height of the fluid for the succeeding 18 hours. The readings were taken at the end of 18 hours and corrected for the capillary rise of the fluid in the tube. Mll determinations were performed at $25 \pm 3^{\circ} \mathrm{C}$.

The dialyzing fluid employed was prepared by mixing $334 \mathrm{cc}$. of 2 per cent $\mathrm{NaCl}, 200$ cc. of $\mathrm{M} / 10 \mathrm{NaHCO}_{3}, 16$ cc. of $\mathrm{M} / 15$ Sörensen's phosphate mixture ( $\mathrm{pH} 7.4$ ) and $10 \mathrm{cc} .4 .2$ per cent $\mathrm{KCl}$ and making up to $1000 \mathrm{cc}$. with water, thus giving the following molecular concentration:

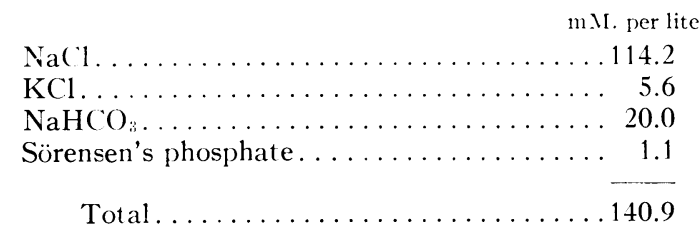

RESULTS

Plasma colloid osmotic pressure measurements and plasma protein fractionations were made on 10 normals (male medical students) and 42 hospital patients. The majority of these patients were on the medical service of St. Luke's Hospital. ${ }^{2}$ These observations are recorded in

${ }^{2}$ We are indebted to I)r. R. II. Scott, Chief of the Medical Division of City Hospital, for a number of our cases. We are also indebted to I)r. R. Dominguez, Pathologist at St. Luke's Hospital, for his cooperation in this work. 
Figure 1. In Figure 1, the group of nephritic cases designated with the symbols $\bigcirc$ and $\boldsymbol{\Delta}$ (cases with and without edema) included the following: Nephrosis, 2; Acute glomerulonephritis, 5; Subacute glomerulonephritis, 3 ; Acute exacerbation of chronic glomerulonephritis, 1 ; Chronic glomerulonephritis, 8.

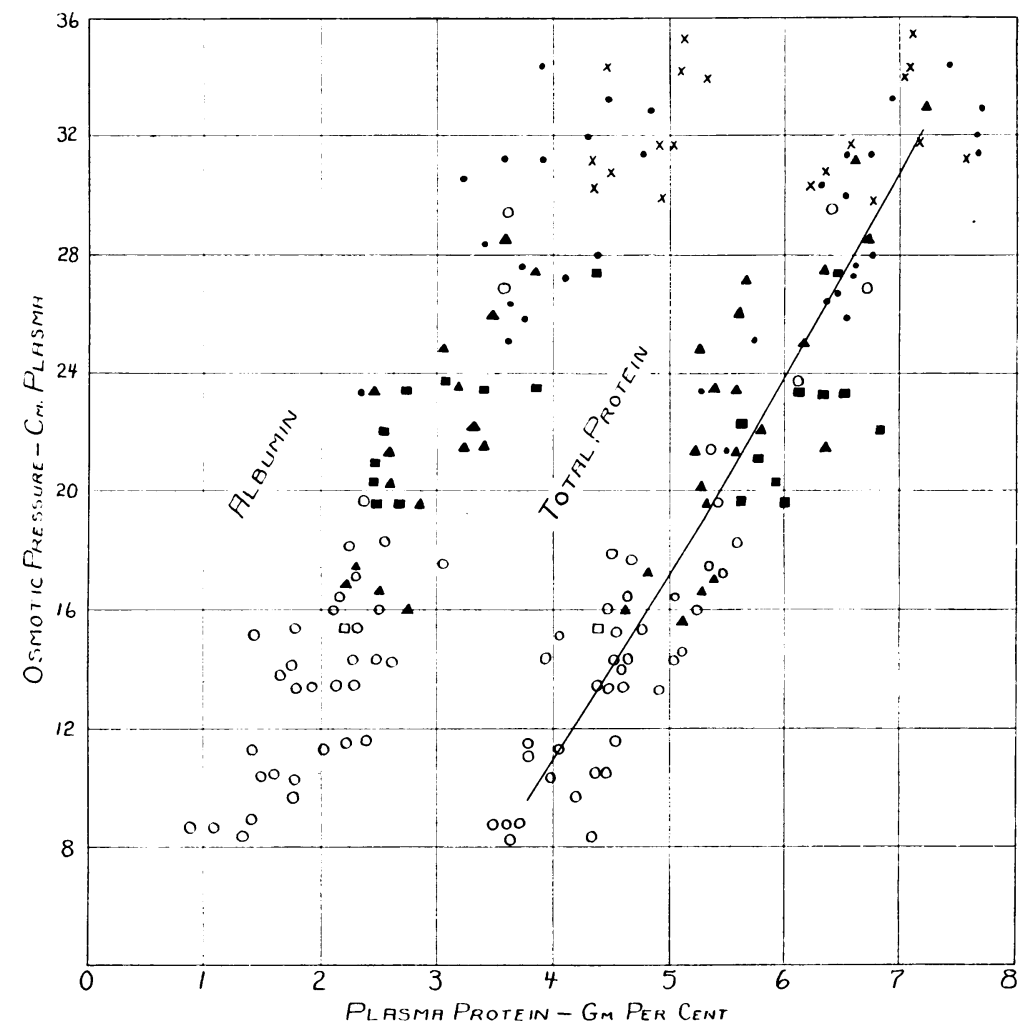

Fig. 1. The Relationship of the Serum Protein to the Colloid Osmotic Pressure

The symbol $\times$ represents normal individuals, $\bullet$ miscellaneous hospital cases, - cardiac cases with edema, $\bigcirc$ nephritis with edema, $\Delta$ nephritis without edema, and $\square$ nutritional edema.

Of this group sixteen had edema at some period during the observation and in six edema disappeared completely on hospitalization.

The miscellaneous hospital cases designated by the symbol $\bullet$ did not have edema and included the following: Hypertension, 9; Pregnancy, 5; Myxedema, 1.

The subjects with hypertension did not have serious renal impairment as was evidenced by little or no blood nitrogen retention.

Table I shows a comparison of the values for the normal plasma colloid osmotic pressures and the total protein concentrations observed in this 
study and found in the literature. The plasma osmotic pressure of the 10 normal male medical students varied from 29.5 to $35.7 \mathrm{~cm}$. plasma with an average value of 32.5 . The total proteins varied from 6.20 to 7.66 per

TABLE I

The range of the normal plasma colloid osmotic pressure

\begin{tabular}{|c|c|c|c|}
\hline & $\begin{array}{l}\text { Number of } \\
\text { observations }\end{array}$ & Protein & $\begin{array}{l}\text { Colloid } \\
\text { osmotic } \\
\text { pressure }\end{array}$ \\
\hline & & per cent & $\left(m . I_{2}()\right.$ \\
\hline Govaerts (1924). & 10 & $7.67-8.69$ & $35.7-39.7$ \\
\hline Schade and Claussen (1924). & 13 & $8.15-9.46$ & $29.9-36.2$ \\
\hline Mayrs (1926). & Mixed sample & 7.88 & 40.2 \\
\hline Verney (1926). & 6 & $6.20-7.0$ & $29.2-33.6$ \\
\hline Cope $(1928)$. & 2 & $6.07-6.56$ & 32 \\
\hline Kylin (1931). & 23 & $6.59-9.78$ & $29.6-37.0$ \\
\hline Iversen and Nakazawa (1927). . & 8 & $7.20-8.28$ & $32.5-40.1$ \\
\hline Fahr, Kerkhof and Conklin (1931)......... & 5 & $6.40-9.0$ & $27.2-33.7$ \\
\hline Present study . . . . . . . . . . . . . . & 10 & $6.20-7.66$ & $29.5-35.7$ \\
\hline
\end{tabular}

cent and the albumin from 4.28 to 5.48 . The average was 6.86 per cent total protein, 4.84 per cent albumin, and 1.88 per cent globulin, with a corresponding albumin:globulin ratio of 2.58 . The plasma colloid osmotic pressure values agree well with the normal figures found in the literature. This is especially true when one considers that somewhat different techniques have been employed by the various workers for the colloid osmotic pressure determinations. Indoubtedly the value for the colloid osmotic pressure obtained will depend to some degree upon the individual technique. The average total plasma protein concentration agrees very well with previously published values. The average albumin: globulin ratio appears to be higher than the average value found by Moore and Van Slyke (1930). It is, however, in agreement with the average value obtained by Bruckman, I)'Esopo and Peters (1930). The latter workers obtained from 27 determinations on 13 adult males total proteins from 6.46 to 7.65 per cent. The average was 6.93, and from their average albumin and globulin figures the calculated albumin : globulin ratio would be 2.68 .

As can be seen in the cases of renal disease with edema there is generally a definite lowering of both the serum protein content and the colloid osmotic pressure. The lowest colloid osmotic pressure observed was 8.1 $\mathrm{cm}$. of plasma accompanied by a total serum protein content of 3.70 per cent. This was observed in a case of nephrosis having marked pitting edema and slight ascites.

In general, the changes in the serum protein and albumin contents were paralleled by changes in the colloid osmotic pressure. Further, in cases of renal disease (not complicated by cardiac disease), edema was 
generally absent when the colloid osmotic pressure attained a value of 20 $\mathrm{cm}$. plasma or more. Exceptions to this, shown in Figure 1, were observed in two cases of acute glomerulonephritis. One of these two cases had marked pitting edema and slight ascites in the presence of a colloid osmotic pressure of $29.5 \mathrm{~cm}$. plasma, a total serum protein content of 6.43 per cent and an albumin content of 3.64 per cent.

With the six cases of nephritis in which edema disappeared when high protein low salt diets were given, the colloid osmotic pressure and the serum protein content showed a definite increase with improvement. However, five of these cases were clinically free from edema when the colloid osmotic pressure was below $20 \mathrm{~cm}$. plasma. One of these cases (case of acute exacerbation of chronic glomerulonephritis) was clinically free from edema with a colloid osmotic pressure of $14.1 \mathrm{~cm}$. plasma, a total serum protein content of 4.68 per cent and an albumin content of 1.75 per cent.

The seven cases with predominant signs of cardiac disease all had edema. The colloid osmotic pressure tended to be lowered in every instance, although the edema was present at a higher colloid osmotic pressure level than in the renal cases.

\section{DISCUSSION}

\section{Plasma protein concentration}

The finding of a decrease in the plasma protein in these cases of nephritis with edema is in accord with the observation of quite a large series of workers. Epstein (1912) noted, in cases which he originally termed chronic parenchymatous nephritis, that the protein concentration was below the normal value. Similar findings have been reported by Rowe (1917), Linder, Lundsgaard and Van Slyke (1924), Blackfan and Hamilton (1927), Peters, Wakeman, Eisenman and Lee (1929), Moore and Van Slyke (1930), Peters, Bruckman, Eisenman, Hald and Wakeman (1931), and others.

Linder, Lundsgaard and Van Slyke (1924) were unable in some cases to show any connection between fluctuations in edema and variations in plasma protein concentration. Recently Moore and Van Slyke (1930) reported that the presence of non-cardiac edema in most cases of nephritis is closely related to the decrease in total protein content and specific gravity of the plasma. In the 75 patients they examined, which included hemorrhagic, degenerative and arteriosclerotic types of renal disease, it was found that when the total protein content fell below the lower limit of the range, $5.5 \pm 0.3$ per cent, or the albumin below $2.5 \pm 0.2$ per cent, edema was usually present. It was found that when the protein concentration was above the upper limits of these ranges, edema was usually absent. 
Peters, Bruckman, Eisenman, Hald and Wakeman (1931), studying patients with nephrosis or nephrotic types of nephritis, found that edema was almost invariably present when the total protein was below 4 per cent, while it was observed in only three instances when the total protein was above 5 per cent. This latter occurred in two patients who, in addition to renal disease, had distinct signs of heart disease with circulatory failure. Further, it was pointed out that although it was sometimes possible to induce some degree of diuresis while the proteins were below 4 per cent, complete elimination of edema was effected under these circumstances in only one instance. When, however, the proteins persistently exceeded 4 per cent, it was possible in every instance to eliminate edema by treatment, unless there was concomitant cardiac disease with decompensation or a complicating acute nephritis or septicemia.

Sixteen of the 19 cases of nephritis observed in this study showed edema in the period of observation. Of the cases showing edema, 7 had initial total plasma protein concentrations between 3 and 4 per cent, 4 between 4 and 5 per cent, 4 between 5 and 5.5 per cent and 1 definitely above 5.5 per cent. This latter was a case of acute glomerulonephritis, a condition in which the edema may not depend directly on the serum protein. Six of the edematous cases when treated with a low salt high protein diet showed complete disappearance of edema. Of these cases, four had on the first observation less than a 4 per cent total serum protein concentration, and three had at the time of complete absence of edema less than a 5 per cent total protein concentration.

\section{Colloid osmotic pressure}

The studies of Starling (1896) indicated that the fluid balance of the organism is dependent upon an approximate balance of two factors, namely the capillary pressure forcing fluid out and the osmotic pressure drawing fluid back into the capillary circulation. This idea was amplified by the studies of Schade, Claussen et al. (1926) on a model capillary. With suitable osmotic pressures of the fluid outside and inside of a membrane and with suitable hydrostatic pressures these workers were able to show that fluid is forced out in the first half of the capillary and pulled back in the second half. Further, they were able to show definitely the influence of changes in both the colloid osmotic pressure and the hydrostatic pressures on the movement of fluid.

As stated above, Epstein (1917) was the first to employ this conception in attempting to explain the occurrence of nephritic edema. This view has been taken up by a number of workers. Kylin (1931), who has recently reviewed the literature concerning the significance of these two factors in the pathogenesis of edema, points out that a number of workers (e.g. Krogh, Koranyi, Schade, Iversen, von Farkas, Ruszniak, Govaerts, etc.) attribute considerable significance to the colloid osmotic pressure, 
while others (e.g. Krehl, Nonnenbruck, Oehme, Meyer, etc.) attribute a greater significance to the condition of the tissues. Kylin takes the view that the decrease of the colloid osmotic pressure at the most can be only one factor which has an influence on the pathogenesis of edema (1930) (1931).

Von Farkas (1928) studied the relationship of the venous pressure to the colloid osmotic pressure and to the extent of edema. When osmotic pressure was plotted against venous pressure, edematous and nonedematous cases were grouped into two areas separated by a critical zone. It was observed that the farther the points representing the edematous cases were from the normal side, the greater was the extent of edema. From this study von Farkas concluded that cardiac as well as nephrotic and cachetic edemas, in which capillary injury is absent, result from physicochemical processes and can be explained without the assumption of secretory activity on the part of the capillaries.

From the observation of the cases reported here we are inclined to the view, expressed by Moore and Van Slyke (1930), that Epstein was right in applying Starling's theory, and that the main and constant factor in producing the tendency towards non-cardiac edema in nephritis is plasma protein deficit. Since the protein deficits are due mainly to decreases in the albumin fraction and these in turn closely parallel the changes in the plasma colloid osmotic pressure, it would seem that the presence or absence of non-cardiac nephritic edema should be correlated with the colloid osmotic pressure as Moore and Van Slyke found it to be correlated with the plasma protein concentration. That this is the case is evident from Figure 1, where it may be seen that edema was usually absent when the plasma colloid osmotic pressure was $20 \mathrm{~cm}$. plasma or more. This value for the colloid osmotic pressure is essentially that observed by Mayrs (1926) but somewhat lower than that of Govaerts (1924) who found that when the osmotic pressure was below $30 \mathrm{~cm}$. water edema was always present.

It apparently is not uncommon to have a complete disappearance of edema in cases under treatment with a low salt intake and diuretics, even though the plasma protein content and colloid osmotic pressure values are below the values which are associated with edema in other cases. The tendency to edema remains, however, until the plasma proteins have risen above the critical level and will return if salt restriction is not continued or the individual incurs a slight infection. This influence of infection was nicely demonstrated in a case of nephrosis who gained 8 pounds in weight during a siege of cold after having been edema free for some time, although a plasma protein deficit persisted. There are instances, however, where undoubtedly some unknown physiological factor must be considered present to explain the occurrence and disappearance of edema. This is especially true in the transient edemas in the first days 
of acute nephritis. The symbols in Figure 1, representing cases of nephritis with edema having plasma colloid osmotic pressure values above $20 \mathrm{~cm}$. plasma, represent observations on two cases of acute glomerulonephritis. Both subjects had colloid osmotic pressure values above 25 $\mathrm{cm}$. plasma and total plasma protein concentrations above 6 per cent in the presence of marked pitting edema.

It would appear that evidence for the importance of the lowered plasma protein or lowered colloid osmotic pressure to the occurrence of edema is furnished by the observations of Bruckman and Peters (1930) who found that in malnutrition an edema results with lowered serum protein. Frisch, Mendel and Peters (1929) also found a low blood protein coincident with edema in white rats fed a low protein diet. Further, Leiter (1931) by repeated plasmapheresis has been able to reduce the serum proteins in dogs, and found that edema appeared when the proteins had fallen to about 3 per cent or less. We had the opportunity to observe a case of nutritional edema (Fig. 1). At the time of observation there was marked emaciation and definite pitting edema of the legs. The total plasma protein concentration was 4.44 per cent, albumin 2.32 per cent and the colloid osmotic pressure $15.0 \mathrm{~cm}$. of plasma.

\section{SUMMARY}

A comparison of the plasma proteins and the plasma colloid osmotic pressure has been made on 10 normals and 42 hospital patients.

The plasma colloid osmotic pressure of the normal subjects was found to vary between 29 and $36 \mathrm{~cm}$. of plasma. The edema of nephritis (not complicated with cardiac disease) is generally accompanied by a lowering of both the plasma protein and the plasma colloid osmotic pressure. When the plasma colloid osmotic pressure attains a value of 19 to $20 \mathrm{~cm}$. plasma or more, edema is generally absent. Exceptions to this rule were observed in two cases of acute glomerulonephritis in which edema was observed with colloid osmotic pressure values above $25 \mathrm{~cm}$. plasma.

Nephritic subjects with edema may show complete disappearance of edema when they have received high protein low salt diets even while plasma colloid osmotic pressure values are below $19 \mathrm{~cm}$. of plasma and total plasma proteins are below 5 per cent. The tendency toward edema still remains, however, until these values increase above their critical levels. With return to normal of the plasma protein there is a parallel increase in the plasma colloid osmotic pressure.

Cardiac cases with edema have a tendency to a lowered colloid osmotic pressure and plasma protein. However, the colloid osmotic pressure in these cases is at a higher level than in cases of nephritis with edema. 


\section{BIBLIOGRAPHY}

Blackfan, K. D., and Hamilton, B., Bull. Johns Hopkins Hosp., 1927, xli, 322. A Study of the Inorganic Constituents of the Serum in Children with Acute Nephritis.

Bruckman, F. S., D'Esopo, L. M., and Peters, J. P., J. Clin. Invest., 1930, viii, 577. The Plasma Proteins in Relation to Blood Hydration. IV. Malnutrition and the Serum Proteins.

Bruckman, F. S., and Peters, J. P., J. Clin. Invest., 1930, viii, 591. The Plasma Proteins in Relation to Blood Hydration. V. Serum Proteins and Malnutritional or Cachectic Edema.

Cope, C. L., Quart. J. Med., 1928, xxii, 91. The Osmotic Pressure of the Blood Proteins in Nephritis.

Epstein, A. A., J. Exper. Med., 1912, xvi, 719. A Contribution to the Study of the Chemistry of Blood Serum.

Epstein, A. A., Am. J. M. Sc., 1917, cliv, 638. Concerning the Causation of Edema in Chronic Parenchymatous Nephritis. Method for Its Alleviation.

Fahr, G., Kerkhof, A., and Conklin, C., Proc. Soc. Exper. Biol. and Med., 1931, xxviii, 720. Osmotic Pressure of Plasma Proteins in Nephritis.

von Farkas, G. V., Ztschr. f. d. ges. exper. Med., 1928, 1xii, 35. Ist das Ödem ein Resultat der Capillarsekretion?

Frisch, R. A., Mendel, L. B., and Peters, J. P., J. Biol. Chem., 1929, lxxxiv, 167. The Production of Edema and Serum Protein Deficiency in White Rats by Low Protein Diets.

Govaerts, P., Bull. Acad. roy. de méd. de Belgique, 1924, iv, 161. Recherches cliniques sur le rôle de la pression osmotique des protéines du sang, dans la pathogénie des oedèmes et de l'hypertension artérielle.

Iversen, P., and Nakazawa, F., Biochem. Ztschr., 1927, cxci, 307. Über die Biochemie des Filtrationsödems.

Kylin, E., Ztschr. f. klin. Med., 1930, cxiv, 309. Studien über die Ödemausschwemmung. VII. Über das Verhalten des kolloidosmotischen Druckes des Blutserums während der Behandlung zweier Fälle mit nephrotischem Ödem.

Kylin, E., Ztschr. f. d. ges. exper. Med., 1931, lxxvii, 289. Studien über den Kolloidosmotischen (Onkotischen) Druck. XIV. Über den intermediären Wasserstoff wechsel bei Ödemenstehung und Ödemausschwemmung.

Kylin, E., Klin. Wchnschr., 1931, x, 1034. Über die Bedeutung des Kolloidosmotischen druckes des Blutes für die Ödempathogenese.

Kylin, E., Klin. Wchnschr., 1931, x, 1351. Studien über den Kolloidosmotischen (Onkotischen) Druck. Über den Kolloidosmotischen Druck bei der Ödemausschwemmung in einem weiteren Falle von Nephrose.

Leiter, L., Arch. Int. Med., 1931, xlviii, 1. Experimental Nephrotic Edema.

Linder, G. C., Lundsgaard, C., and Van Slyke, D. D., J. Exper. Med., 1924, xxxix, 887. The Concentration of the Plasma Proteins in Nephritis.

Mayrs, E. B., Quart. J. Med., 1926, xix, 273. The Functional Pathology of Nephritis.

Moore, N. S., and Van Slyke, D. D., J. Clin. Invest., 1930, viii, 337. The Relationships between Plasma Specific Gravity, Plasma Protein Content and Edema in Nephritis.

Peters, J. P., Bruckman, F. S., Eisenman, A. J., Hald, P. N., and Wakeman, A. M., J. Clin. Invest., 1931, x, 941. The Plasma Proteins in Relation to Blood Hydration. VI. Serum Proteins in Nephritic Edema. 
Peters, J. P., Wakeman, A. M., Eisenman, A. J., and Lee, C., J. Clin. Invest., 1929, vi, 517. Total Acid-Base Equilibrium of Plasma in Health and Disease. $\mathrm{X}$. The Acidosis of Nephritis.

Rowe, A. H., Arch. Int. Med., 1917, xix, 354. Refractometric Studies of Serum Proteins in Nephritis, Cardiac Decompensation, Diabetes, Anemia and other Chronic Diseases.

Schade, H., and Claussen, F., Ztschr. f. klin. Med., 1924, c, 363. Der Onkotische Druck des Blutplasmas und die Entstehung der renal bedingten Ödeme.

Schade, H., Claussen, F., Häbler, C., Hoff, F., Mochizucki, N., and Birner, M., Ztschr. f. d. ges. exper. Med., 1926, xlix, 334. Weitere Untersuchungen zur Molekularpathologie der Entzündung: Die Exsudate.

Starling, E. H., J. Physiol., 1895-96, xix, 312. On the Absorption of Fluids from the Connective Tissue Spaces.

Verney, E. B., J. Physiol., 1926, lxi, 319. The Osmotic Pressure of the Proteins of Human Serum and Plasma. 